\title{
Pembelajaran Biologi SMA Abad ke-21 Berbasis Potensi Lokal: Review Potensi di Kabupaten Nunukan-Kalimantan Utara
}

\author{
I. Ismiati \\ Sekolah Menengah Atas (SMA) Negeri 1 Nunukan, Jl. Fatahillah No.137, RT.10, Nunukan Tim., Kec. \\ Nunukan, Kabupaten Nunukan, Kalimantan Utara 77482, Indonesia \\ *Corresponding Author e-mail: ismiati.sman1nunukan@gmail.com
}

Received: June 2020; Revised: June 2020; Published: July 2020

\begin{abstract}
Abstrak
Pembelajaran biologi perlu mendayagunakan potensi dan ruang lingkup lokal karena biologi haruslah relevan dengan kehidupan dan kebutuhan peserta didik. Salah satu daerah yang perlu diarusutamakan adalah Kabupaten Nunukan, Provinsi Kalimantan Utara. Artikel ini bertujuan mendeskripsikan kontek pembelajaran biologi di jenjang SMA pada abad ke-21 berbasis potensi daerah Kepulauan Nunukan. Kajian ini menggunakan metode studi literatur dan analisis isi. Studi literatur dilakukan dengan mensurvei buku, artikel ilmiah, dan sumber lain yang relevan dengan masalah tertentu, bidang kajian, atau teori, dan dengan demikian, memberikan deskripsi, ringkasan, dan evaluasi kritis dari karyakarya ini sehubungan dengan masalah yang sedang diselidiki. Berdasarkan telusur literatur diketahui bahwa dari aspek flora dan fauna ada 15 potensi yang dapat dijadikan dasar atau pengembangan sumber belajar/bahan ajar biologi. Dari aspek ekologi dan sosial ada 6 potensi. Dengan demikian, sejauh ini minimal ada 21 potensi yang dapat dijadikan bahan oleh guru biologi SMA di Kabupaten Nunukan ketika mengajar. Tentu saja, setiap potensi disesuaikan dengan Kompetensi Inti, Kompetensi Dasar, dan Indikator yang telah ditetapkan. Angka tersebut tentu akan terus berkembangan seiring dengan gencarnya penelitian yang dilakukan oleh para peneliti lokal maupun internasional.

Kata Kunci: Abad ke-21, Pembelajaran biologi, Potensi local, Sekolah menengah atas
\end{abstract}

\section{The $21^{\text {st }}$ Century High School Biology Learning Based on Local Potency: Review of Potency in Nunukan Regency, North Kalimantan}

\begin{abstract}
Biology learning needs to utilize local potential and scope because biology must be relevant to the lives and needs of students. One area that needs to be mainstreamed is Nunukan Regency, North Kalimantan Province. This article aims to describe the context of learning biology in the 21st century high school based on the potential of the Nunukan Islands region. This study uses literature study and content analysis methods. Literature studies are conducted by surveying books, scientific articles, and other sources that are relevant to a particular problem, field of study, or theory, and as such, provide a description, summary, and critical evaluation of these works in connection with the problem being investigated. Based on the literature search, it is known that from the aspect of flora and fauna there are 15 potentials that can be used as a basis or development of learning resources / teaching materials in biology. From the ecological and social aspects there are 6 potentials. Thus, so far there are at least 21 potentials that can be used as materials by high school biology teachers in Nunukan Regency when teaching. Of course, each potential is adjusted to the Core Competencies, Basic Competencies and Indicators that have been set. This figure will certainly continue to develop along with the incessant research conducted by local and international researchers.
\end{abstract}

Keywords: The 21st century, Biology learning, Local potency, High school

How to Cite: Ismiati, I. (2020). Pembelajaran Biologi SMA Abad ke-21 Berbasis Potensi Lokal: Review Potensi di Kabupaten Nunukan-Kalimantan Utara. Jurnal Penelitian dan Pengkajian Ilmu Pendidikan: eSaintika, 4(2), 234-247. doi:https:// doi.org/10.36312/e-saintika.v4i2.218 


\section{PENDAHULUAN}

Beberapa dekade terakhir, biologi telah berevolusi dari ilmu klasik (deskriptif) ke modern (penjelasan/ explanatory). Setelah era teknik (abad ke-19), kimia dan fisika (abad ke-20), biologi telah mulai memainkan peran kunci dalam mengatasi masalah global/kompleks di abad ke-21 (Torkar \& Kubiatko, 2017). Seperti yang belum pernah terjadi sebelumnya, kemajuan dalam ilmu biologi memegang peran yang luar biasa untuk mengatasi banyak tantangan utama yang dihadapi dunia (National Academy of Sciences, 2009). Perkembangan dan capaian dalam biologi itu harus disampaikan dalam bentuk pembelajaran biologi di kelas (Khalil, Lazarowitz, \& Hertz-Lazarowitz, 2014; Novick \& Catley, 2016). Bahkan, pendekatan interdisipliner untuk Biologi, Teknologi, dan Matematika disarankan untuk menyerap 21 keterampilan abad ke-21 dalam kurikulum biologi yang ada (Hiong \& Osman, 2013).

Tujuan utama dari mata pelajaran Biologi adalah untuk membekali perserta didik dengan keterampilan dan pengetahuan dalam Ilmu Pengetahuan dan Teknologi, yang memungkinkan mereka untuk memecahkan masalah dan membuat keputusan dalam kehidupan sehari-hari berdasarkan pada sikap ilmiah dan nilai-nilai moral (Anelli, 2011; Boleng, Lumowa, Palenewen, \& Corebima, 2017; Maranan, 2017; Suwono, Mahmudah, \& Maulidiah, 2017). Peserta didik di abad ke-21 ini harus disiapkan untuk menjadi masyarakat global (Husamah, Hudha, \& Putri, 2019; NEA, 2012). Sehubungan dengan itu, kurikulum Biologi diadaptasi untuk memasukkan keterampilan abad ke-21 seperti keterampilan ilmiah, keterampilan berpikir kreatif dan kritis, keterampilan proses sains dan sikap ilmiah serta nilai-nilai moral. Keterampilan abad ke-21 ditekankan pada penciptaan peserta didik yang mampu menerapkan teknologi melalui literasi era digital, kreatif dan kritis dalam pemikiran mereka dan memiliki keterampilan interpersonal dan sosial yang sangat baik (Arsad, Osman, \& Soh, 2011; Kustiani, Zaini, \& Mulyadi, 2020). Pendidikan sains-termasuk biologi-untuk peserta didik berada pada posisi penting, karena mereka dihadapkan dengan tantangan ilmiah yang sangat besar yang harus mereka hadapi saat ini (Anderman \& Sinatra, 2009; Chen \& Huang, 2017). Oleh karena itu, guru harus siap dan mampu mengimplementasikan aspek keterampilan abad ke-21 dalam kegiatan belajar mengajar biologi (Francisca \& Samsudin, 2018; Haviz, Karomah, Delfita, Umar, \& Maris, 2018; Yanti, Maridi, \& Sutarno, 2019).

Partnership for 21st Century Skills telah mengidentifikasi enam elemen kunci abad ke-21 dalam mendorong pembelajaran, tiga dari enam elemen kunci adalah (1) penggunaan alat abad ke-21 untuk mengembangkan keterampilan belajar; siswa perlu belajar bagaimana menggunakan alat yang penting untuk kehidupan seharihari. (2) Belajar dan pembelajaran dalam konteks abad ke-21; siswa belajar materi melalui contoh, aplikasi, dan pengalaman dunia nyata baik di dalam maupun di luar sekolah. (3) Mengajar dan mempelajari konten abad ke-21; pendidik perlu mengintegrasikan pengetahuan dan keterampilan di abad ke-21 (Swandi, Amin, \& Muin, 2018). Guru adalah faktor utama yang berkontribusi pada pembelajaran abad ke-21 yang memiliki empat aspek, yaitu 1) kreativitas, 2) berpikir kritis, 3) komunikasi, 4) kolaborasi (Fauzi, 2019; Janetos, 2020; Muhlisin, 2017; Suganda \& Purwianiangsih, 2020).

Sehubungan dengan itu, saat ini diperlukan upaya menciptakan budaya dan struktur sosial dan pendidikan yang akan memfasilitasi dan memelihara pengembangan alat sekarang dan di masa depan. Ilmuwan membutuhkan lebih dari sekadar teknologi, perangkat, dan perangkat lunak baru; mereka juga perlu menciptakan dan mendukung budaya sains dan pendidikan yang merangsang dan 
menumbuhkan kreativitas, mendukung pembuat alat potensial, dan melatih generasi berikutnya (Robinson et al., 2010). Proses tersebut diperlukan di level sekolah menengah. Salah satu jenjang pendidikan yang perlu mendapat perhatian dalam konteks pembelajaran biologi adalah jenjang sekolah menengah atas (SMA). Pembelajaran biologi di SMA sangat penting untuk membekali peserta didik, sebelum menempuh perkuliahan di perguruan tinggi (Afandi, Chamalah, \& Wardani, 2013; Rahmaniati, 2016; Wahyullah, 2014).

Sejalan dengan tuntutan itu, pembelajaran biologi perlu mendayagunakan potensi dan ruang lingkup lokal (Asikin, Irawati, \& Syamsuri, 2016; Hernawati, Amin, Al Muhdhar, \& Indriwati, 2019; Mendala \& Suryadarma, 2019; Mumpuni, Susilo, \& Rohman, 2013), karena biologi haruslah relevan dengan kehidupan dan kebutuhan peserta didik (Chamany, Allen, \& Tanner, 2008). Implementasi pembelajaran yang mendayagunakan potensi dan keunggulan lokal dimungkinkan mampu meningkatkan kemampuan konten, konteks, dan proses sains peserta didik (Nofiana \& Julianto, 2018), yang selaras dengan tuntutan abad ke-21 (Abidinsyah, Ramdiah, \& Royani, 2019). Upaya tersebut harus terus digalakkan, karena jumlahnya masih terbatas dan belum merata (Abrori, 2017; Ilma \& Wijarini, 2017; Zukmadini, Jumiarni, \& Kasrina, 2018).

Dalam hubungannya dengan pendayagunaan potensi dan ruang lingkup lokal, salah satu daerah yang perlu diarusutamakan adalah Kabupaten Nunukan, Provinsi Kalimantan Utara. Kabupaten Nunukan merupakan daerah yang berbentuk pulaupulau kecil dan kepulauan besar (Helmiati, 2016). Kabupaten Nunukan adalah salah satu kabupaten terluar di Indonesia. Kabupaten ini masih tergolong sebagai daerah tertinggal dari sisi sosial-ekonomi (Giyarsih, 2014; Helmiati, 2016; Solihin, Wisudo, Haluan, \& Martianto, 2011). Aspek pendidikan perlu diperhatikan dan dikembangkan sehingga dapat sejajar dengan kualitas pendidikan di kota/kabupaten lain di Indonesia maupun di negara-negara tetangga (Asri, 2017; Bonati, 2018; Partnership for Governance Reform, 2011; Rosliana et al., 2015; Sudarwan \& Lay, 2011). Oleh karena itu artikel ini bertujuan mendeskripsikan kontek pembelajaran biologi di jenjang SMA pada abad ke-21 berbasis potensi daerah Kepulauan Nunukan-Kalimantan Utara. Review ini memiliki dapat memberikan gambaran awal untuk penelitian dan pengembangan pembelajaran biologi pada jenjang SMA di daerah terluar, terdepan, maupun daerah yang membutuhkan perhatain lebih seperti salah satunya adalah Kabupaten Nunukan.

\section{METODE}

Kajian atau review ini menggunakan perspektif atau metode studi literatur dan analisis isi (konten), mengikuti pandangan Fink (2014) dan Caulley (2007). Studi literatur dilakukan dengan mensurvei buku-buku, artikel ilmiah, dan sumber-sumber lain yang relevan dengan masalah tertentu, bidang kajian, atau teori, dan dengan demikian, memberikan deskripsi, ringkasan, dan evaluasi kritis dari karya-karya ini sehubungan dengan masalah yang sedang diselidiki. Studi literatur dirancang untuk memberikan gambaran tentang sumber yang telah dijelajahi saat meneliti/mengkaji topik tertentu dan untuk menunjukkan kepada pembaca bagaimana kajian tersebur cocok dalam bidang studi yang lebih besar.

Sementara itu analisis isi adalah "teknik penelitian untuk membuat kesimpulan yang dapat ditiru dan valid dari teks (atau hal lain yang bermakna) ke konteks penggunaannya". Gagasan inferensi sangat penting dalam analisis konten. Penulismenggunakan konstruksi analitik, atau aturan inferensi, untuk beralih dari 
teks ke jawaban pertanyaan penelitian. Dua domain, teks dan konteks, secara logis independen, dan peneliti menarik kesimpulan dari satu domain independen (teks) ke domain lainnya (konteks). Konstruksi analitis dapat berasal dari (1) teori atau praktik yang ada; (2) pengalaman atau pengetahuan para ahli; dan (3) penelitian sebelumnya (White \& Marsh, 2006).

Sehubungan dengan itu, penulis telah menelusuri berbagai literatur yang bersifat primer. Telusur dilakukan melalui media online (daring) dengan bantuan mesin pencari Google. Literatur tersebut, yaitu yaitu berbagai artikel ilmiah yang diterbitkan di jurnal ilmiah dan prosiding (baik nasional maupun internasional), berbagai laporan penelitian/kegiatan, makalah, buku, surat kabar, peraturan/kebijakan pemerintah (pusat maupun daerah), berita daring, dan berbagai sumber literatur lainnya. Untuk memastikan kevalidan dan reputasi sumber, maka penulis hanya menggunakan sumber yang memiliki URL sehingga bila suatu saat diperiksa oleh pembaca maka akan tetap tertelusur. Kata kunci yang digunakan untuk menelusur literatur di Google adalah "Kabupaten Nunukan", "Biologi Nunukan", "Biologi dan Potensi Lokal", "Biologi and 21st Century", "Biologi SMA Abad 21 dan Potensi Lokal", "Data Nunukan", "Pembelajaran Biologi Berbasis Potensi Lokal", "Pembelajaran Biologi SMA Kepulauan", dan "Pendidikan Nunukan".

\section{HASIL DAN PEMBAHASAN}

Penulis telah menelusur berbagai literatur yang terkai dengan potensi biologi di Kabupaten Nunukan dan daerah di sekitarnya yang masih termasuk Provinsi Kalimantan Utara. Adapun hasilnya sebagaimana disajikan pada Tabel 1.

Tabel 1. Data biologi nunukan dan daerah di sekitarnya

\begin{tabular}{|c|c|}
\hline \multirow{2}{*}{\multicolumn{2}{|c|}{$\begin{array}{l}\text { Potensi Biologi } \\
\text { Flora dan Fauna }\end{array}$}} \\
\hline & \\
\hline 1. Ekosistem mangrove & (Sawitri, Bismark, \& Karlina, 2013) \\
\hline $\begin{array}{l}\text { 2. Studi Bio-epidemiologi dan } \\
\text { Analisis Spasial Kasus Malaria } \\
\text { Daerah Lintas Batas Indonesia - } \\
\text { Malaysia }\end{array}$ & $\begin{array}{l}\text { (Boewono, Widiarti, Ristiyanto, \& } \\
\text { Widyastuti, 2012) }\end{array}$ \\
\hline $\begin{array}{l}\text { 3. Karakteristik Habitat Larva } \\
\text { Anopheles spp }\end{array}$ & $\begin{array}{l}\text { (Sugiarto, Kesumawati Hadi, Soviana, \& } \\
\text { Hakim, 2016) }\end{array}$ \\
\hline $\begin{array}{l}\text { 4. Ikan pepija atau Harpadon } \\
\text { neherius (distribusi temporal dan } \\
\text { spasial, serta pemanfaatan } \\
\text { berkelanjutan) }\end{array}$ & (Laga A, Affandi R, Muchsin I, 2015) \\
\hline 5. Udang dan ikan demersal & (Sugiarto et al., 2016) \\
\hline $\begin{array}{l}\text { 6. Komunitas burung bawah tajuk } \\
\text { di hutan perbatasan (terdapat } 44 \\
\text { jenis dari } 13 \text { famili, jumlah } \\
\text { individu } 186 \text { ekor }\end{array}$ & (Irham, 2015) \\
\hline $\begin{array}{l}\text { 7. Alat Penangkapan Ikan dan jenisi } \\
\text { ikan yag ditemukan (6 jenis alat } \\
\text { tangkap, dengan jenis ikan } \\
\text { berupa Pampus argenteus, } \\
\text { Stromateus niger, Scomberomorus }\end{array}$ & (Husin, 2018) \\
\hline
\end{tabular}




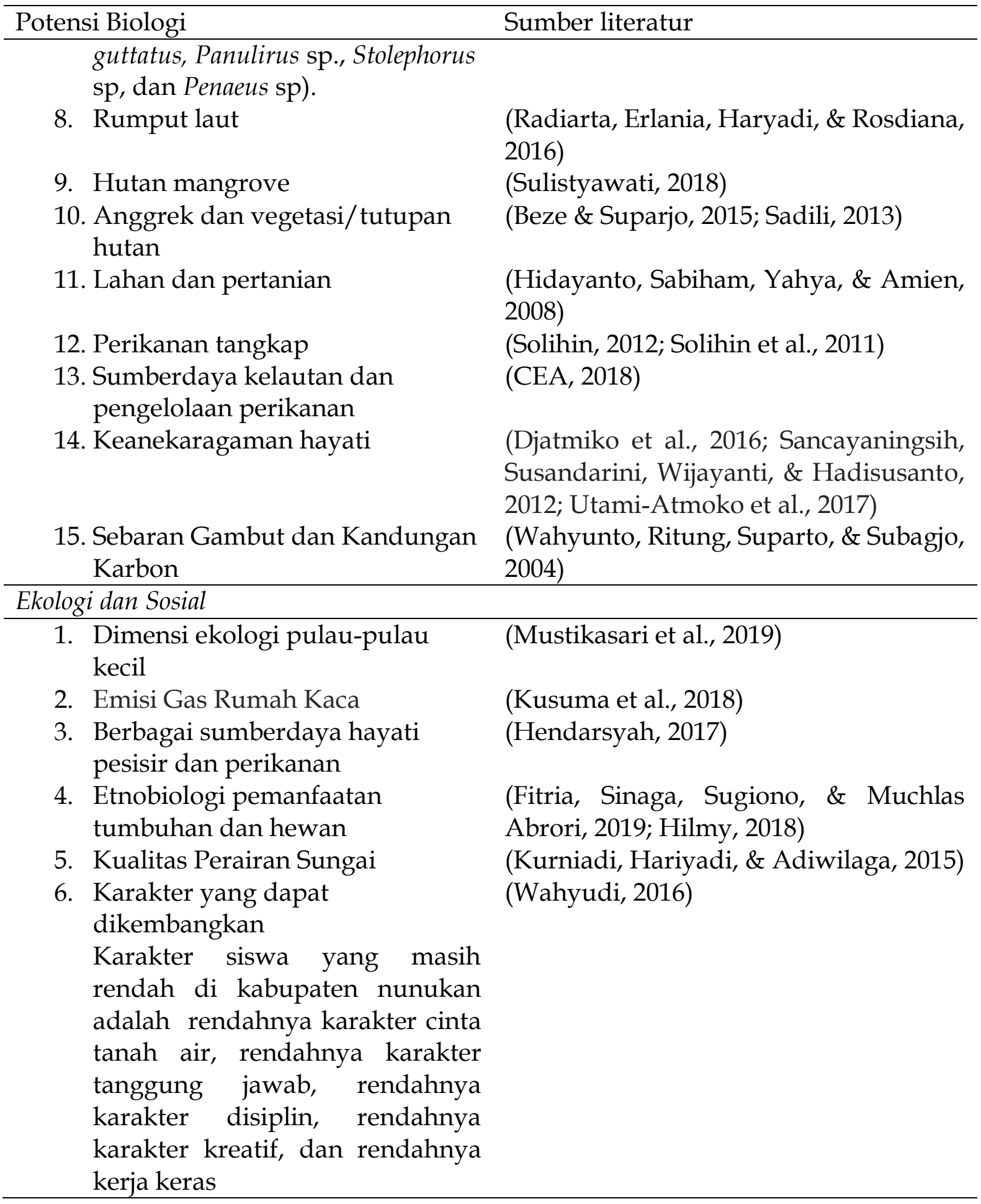

Berdasarkan Tabel 1 diketahui bahwa dari aspek flora dan fauna ada 15 potensi yang dapat dijadikan dasar atau pengembangan sumber belajar/bahan ajar biologi. Sementara dari aspek ekologi dan sosial ada 6 potensi. Dengan demikian, sejauh ini minimal ada 21 potensi yang dapat dijadikan bahan oleh guru biologi SMA di Kabupaten Nunukan ketika mengajar. Tentu saja, setiap potensi disesuaikan dengan Kompetensi Inti, Kompetensi Dasar, dan Indikator yang telah ditetapkan. Angka tersebut tentu akan terus berkembangan seiring dengan gencarnya penelitian yang dilakukan oleh para peneliti lokal maupun internasional. Atas dasar informasi itu, para guru juga seharusnya terinspirasi untuk mengeksplorasi potensi yang ada di daerah sekitar mereka. Hal ini mengingat Kabupaten Nunukan merupakan Kabupaten kepulauan dan memiliki banyak sungai, yang tentu saja ada begitu banyak 
kekayaan dan potensi biologi di setiap pulau-pulau tersebut.

Menurut data SIMTARU (2016) "Kabupaten Nunukan yang terletak antara $115^{\circ} 33^{\prime}$ sampai dengan $118^{\circ} 3^{\prime}$ Bujur Timur dan $3^{\circ} 15^{\prime} 00^{\prime \prime}$ sampai dengan $4^{\circ} 24^{\prime} 55^{\prime \prime}$ Lintang Utara merupakan wilayah paling utara dari Propinsi Kalimantan Utara. Posisinya berada di daerah perbatasan Indonesia - Malaysia. Kabupaten Nunukan di sebelah Utara berbatasan langsung dengan Negara Malaysia Timur-Sabah, sebelah Timur dengan Laut Sulawesi, sebelah Selatan dengan Kabupaten Bulungan dan Kabupaten Malinau, sebelah Barat berbatasan dengan Negara Malaysia Timur Serawak. Kabupaten Nunukan berdiri 1999, hasil pemekaran dari Kabupaten Bulungan dengan luas wilayah 14.247,50 km2. Terdapat 10 sungai dan 29 pulau di Kabupaten ini. Sungai Sembakung merupakan sungai terpanjang $(278 \mathrm{~km})$ dan terpendek adalah Sungai Tabur $(30 \mathrm{~km})$. Topografi Kabupaten Nunukan cukup bervariasi, kawasan perbukitan terjal terdapat di sebelah utara bagian barat, perbukitan sedang di bagian tengah dan dataran bergelombang landai di bagian timur memanjang hingga ke pantai sebelah timur. Perbukitan terjal di sebelah utara merupakan jalur pegunungan dengan ketinggian $1.500 \mathrm{~m}-3.000 \mathrm{~m}$ di atas permukaan laut. Kemiringan untuk daerah dataran tinggi berkisar antara $8-15 \%$, sedangkan untuk daerah perbukitan memiliki kemiringan yang sangat terjal, yaitu di atas 15\%. Dengan demikian kemiringan rata-rata berkisar antara 0 - 50\%." Adapun peta Kabupaten Nunukan disajikan pada Gambar 1.

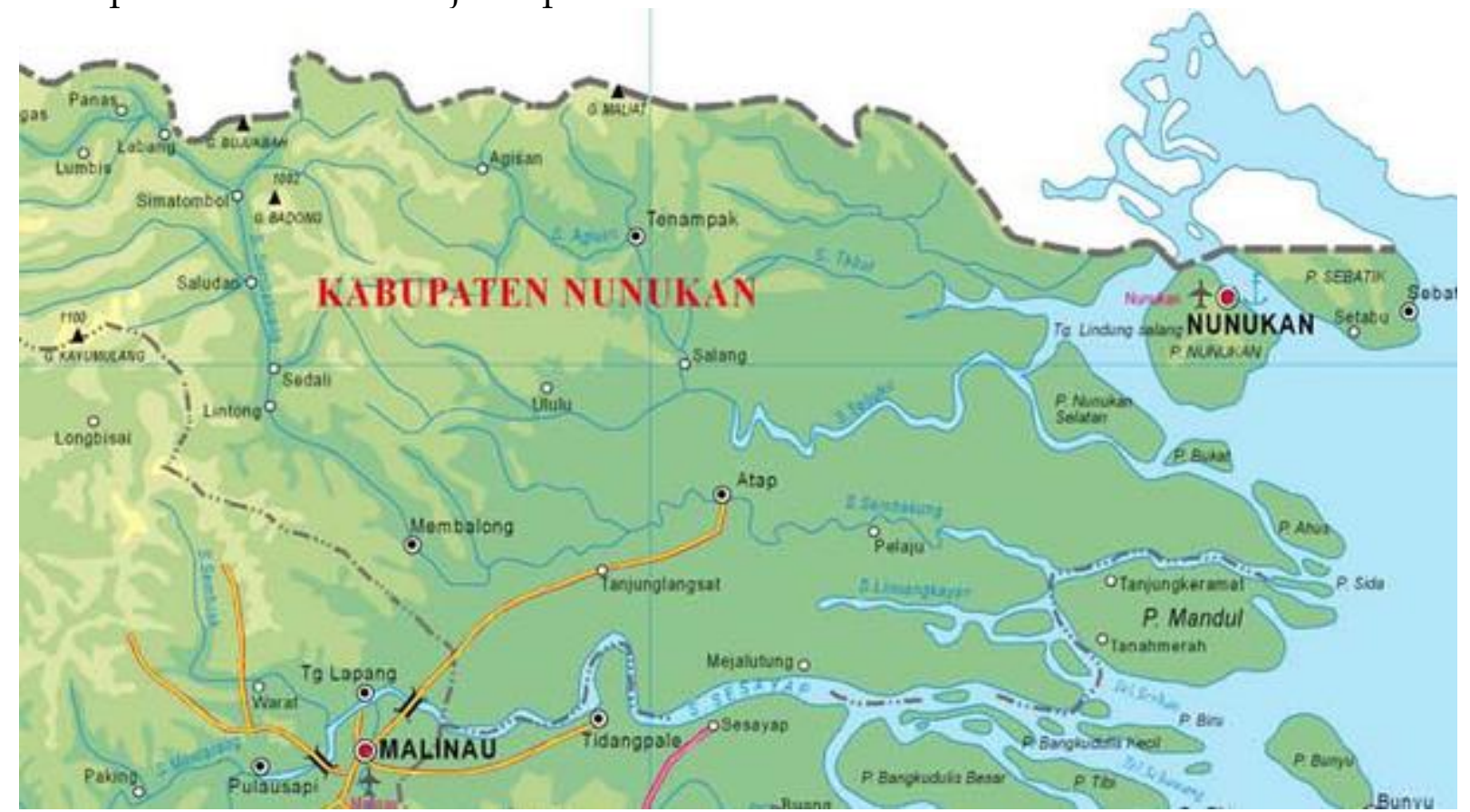

Gambar 1. Peta Kabupaten Nunukan (Afif, 2016)

Kabupaten Nunukan memiliki posisi strategis karena terletak di wilayah perbatasan Indonesia-Malaysia (Hadi \& Kumoro, 2008). Kabupaten Nunukan memiliki berbagai sumber daya alam yang potensial (Beze \& Suparjo, 2015; Presilla, 2011), yang belum dapat diawasi dan dikembangkan secara maksimal. Pengembangan pulau-pulau kecil memiliki karakteristik khusus dan cenderung khas pada aspek sumberdaya alam, aspek lingkungan, dan aepek budaya (Siregar, 2008). Di masa lalu, pembangunan di Nunukan cenderung terabaikan, minim sentuhan modernisasi serta globalisasi. Akan tetapi, dewasa ini perhatian serta kesadaran pemerintah (pusat maupun daerah), pengusaha, dan masyarakat setempat terus meningkat (Maunat, Ardhana, Zaenuddin, \& Presila, 2010). 
Potensi biologi lokal yang ada di Kabupaten Nunukan yang dapat digunakan sebagai sumber belajar perlu disesuaikan dengan tuntutan pembelajaran bioligi abad ke-21. Menurut Ramdiah, Abidinsyah, Royani, Husamah, dan Fauzi (2020) pembelajaran biologi dapat dikembangkan dengan mengandalkan keunikan dan potensi kelimpahan suatu daerah, termasuk budaya dan teknologi lokal (tradisional). Pengembangan alat pembelajaran yang terintegrasi dengan kearifan lokal diharapkan dapat mengembangkan potensi masing-masing daerah dan meningkatkan kreativitas dan karakter siswa. Penekanan pada kearifan lokal sebagai ilmu adat dalam pembelajaran biologi dianggap sangat diperlukan. Pemanfaatan konten kearifan lokal dalam pembelajaran, selain mampu menyelamatkan pengetahuan kearifan lokal juga dapat membantu siswa dalam belajar biologi dengan pembelajaran kehidupan nyata, yang dekat dengan kehidupan sehari-hari mereka. Selain itu, belajar dengan kearifan lokal dapat meningkatkan hubungan siswa dengan masyarakat sekitar dan dapat menghubungkan pengetahuan lokal dengan pengetahuan modern. Ini tentu saja sejalan dengan konsep bahwa hasil yang diharapkan dari pembelajaran biologi adalah agar siswa memiliki literasi sains dan lingkungan. Ini menunjukkan bahwa konteks lingkungan tidak dapat dipisahkan dalam pembelajaran biologi.

Kegiatan pembelajaran yang cenderung monoton, hanya didominasi ceramah, minim praktik, dan jauh dari realitas keseharian mereka akan menyebabkan peserta didik merasa bosan. Mereka pun akan sulit memahami materi biologi yang disampaikan guru. Hal ini tentu dapat berdampak buruk bagi peserta didik karena tujuan belajar dan kompetensi yang telah ditetapkan tidak akan tercapai (Abdillah \& Kristanto, 2015; Muntiani, 2015; Triani et al., 2018). Ketidaktercapaian dan ketidakpuasan peserta didik terhadap hasil yang mereka peroleh seharusnya menjadi tantangan bagi guru untuk terus-menerus memperbaiki proses pembelajaran (Rahmida, 2011). Dalam konteks ini, maka guru sudah semestinya mulai melirik dan mengangkat potensi lokal (Prabowo, Nurmiyati, \& Maridi, 2016; Suratsih, 2010; Susilo, 2018). Apabila perbaikan pembelajaran tidak dilakukan maka akan berpengaruh pada memberikan pemahaman konsep siswa dan selanjutnya pada hasil belajar (Arnetis, Suryawati, \& Anggraini, 2013; Muntiani, 2015; Natsir, 2016).

\section{KESIMPULAN}

Berdasarkan telusur literatur diketahui bahwa dari aspek flora dan fauna ada 15 potensi yang dapat dijadikan dasar atau pengembangan sumber belajar/bahan ajar biologi. Dari aspek ekologi dan sosial ada 6 potensi. Dengan demikian, sejauh ini minimal ada 21 potensi yang dapat dijadikan bahan oleh guru biologi SMA di Kabupaten Nunukan ketika mengajar. Tentu saja, setiap potensi disesuaikan dengan Kompetensi Inti, Kompetensi Dasar, dan Indikator yang telah ditetapkan. Angka tersebut tentu akan terus berkembangan seiring dengan gencarnya penelitian yang dilakukan oleh para peneliti lokal maupun internasional. Potensi biologi lokal yang ada di Kabupaten Nunukan yang dapat digunakan sebagai sumber belajar perlu disesuaikan dengan tuntutan pembelajaran bioligi abad ke-21. Dalam konteks ini, maka guru sudah semestinya mulai melirik dan mengangkat potensi lokal. Apabila perbaikan pembelajaran tidak dilakukan maka akan berpengaruh pada memberikan pemahaman konsep siswa dan selanjutnya pada hasil belajar.

\section{SARAN}

Guru merupakan salah satu garda terdepan dalam menentukan kualitas pendidikan, khususnya di sekolah. Guru-guru akan menjadi inspirasi bagi peserta 
didiknya di ruang-ruang kelas. Sehubungan dengan itu, para guru biologi, khususnya di SMA-SMA Kabupaten Nunukan terus menggali dan memanfaatkan potensi lokal yang ada. Guru juga perlu melakukan penelitian (baik itu penelitian tindakan kelas, quasi-eksperimen, dan penelitian-pengembangan) yang terkait penggunaan potensi biologi lokal Kabupaten Nunukan.

\section{UCAPAN TERIMA KASIH}

Penulisan artikel ini didukung oleh Kepala SMA Negeri 1 Nunukan, Kalimanta Utara, sehingga sepatutnya kami menyampaikan terimak kasih yang sebesarbesarnya. Terima kasih pula kepada Kepala Dinas Pendidikan Kabupaten Nunukan yang terus mendorong para guru untuk menulis dan menginspirasi.

\section{DAFTAR PUSTAKA}

Abdillah, P. R., \& Kristanto, A. (2015). Pengembangan media komputer pembelajaran mata pelajaran biologi materi struktur dan fungsi jaringan hewan vertebrata pada siswa kelas XI SMA Negeri 1 Gondang Mojokerto. Jurnal Mahasiswa Teknologi Pendidikan, 6(3), 1-10.

Abidinsyah, A., Ramdiah, S., \& Royani, M. (2019). The implementation of local wisdom-based learning and HOTS-based assessment: Teacher survey in Banjarmasin. JPBI (Jurnal Pendidikan Biologi Indonesia), 5(3), 407-414. https:/ / doi.org/10.22219/jpbi.v5i3.9910

Abrori, F. M. (2017). Kajian folk taxonomy tumbuhan bumbu dan rempah di daerah Guluk-guluk Sumenep Madura sebagai booklet bagi masyarakat. JPBI (Jurnal Pendidikan Biologi Indonesia), 3(1), 55-63. Retrieved from 10.22219/jpbi.v3i1.3964

Afandi, M., Chamalah, E., \& Wardani, O. P. (2013). Model dan metode pembelajaran di sekolah. In G. Gunarto (Ed.), Perpustakaan Nasional Katalog Dalam Terbitan (KDT). https:/ / doi.org/10.1007/s00423-006-0143-4

Afif, M. F. (2016). Profil Kabupaten Nunukan. Retrieved June 22, 2020, from Indonesia Mengajar website: https://indonesiamengajar.org/kabar-terbaru/profilkabupaten-nunukan

Anderman, E. M., \& Sinatra, G. M. (2009). The challenges of teaching and learning about science in the 21st century: Exploring the abilities and constraints of adolescent learners. Retrieved from https:/ / sites.nationalacademies.org/cs/groups/dbassesite/documents/webpa ge/dbasse_072608.pdf

Anelli, C. (2011). Scientific literacy: What is it, are we teaching it,and does it matter? American Entomologist, 57(4), 235-244. https://doi.org/10.1093/ae/57.4.235

Arnetis, A., Suryawati, E., \& Anggraini, S. F. (2013). Korelasi hasil belajar mahasiswa pada mata kuliah struktur hewan dengan perkembangan hewan di program studi pendidikan biologi FKIP UR 2012/2013. Jurnal Biogenesis, 10(1), 33-43.

Arsad, N. M., Osman, K., \& Soh, T. M. T. (2011). Instrument development for 21st century skills in Biology. Procedia - Social and Behavioral Sciences, 15, 1470-1474. https://doi.org/10.1016/j.sbspro.2011.03.312

Asikin, N., Irawati, mimien henie, \& Syamsuri, I. (2016). Pembelajaran biologi berpendekatan saintifik model sains teknologi masyarakat untuk meningkatkan hasil belajar siswa. Jurnal Pedagogi Hayati, 1(1), 1-10. Retrieved from https://ojs.umrah.ac.id/index.php/pedagogihayati/article/view/32

Asri, S. (2017). Kebijakan pemerataan dan peningkatan mutu pendidikan di wilayah perbatasan. CENDEKIA : Jurnal Pendidikan Dan Pengajaran, 1(1), 25-43. Retrieved 
from

https://www.ojs2.ikippgrikaltim.ac.id/index.php/Cendekia/article/view/4

Beze, H., \& Suparjo, S. (2015). Analisa Tutupan Hutan Pulau Nunukan Kabupaten

Nunukan Kalimantan Utara. Jurnal Digit, 5(1), 1-12. Retrieved from https://jurnaldigit.org/index.php/DIGIT/article/view/56

Boewono, D. T., Widiarti, W., Ristiyanto, R., \& Widyastuti, U. (2012). Studi bioepidemiologi dan analisis spasial kasus malaria daerah lintas batas Indonesia Malaysia (Pulau Sebatik) Kabupaten Nunukan, Provinsi Kalimantan Timur. Buletin Penelitian Kesehatan, 1(1), $2084 . \quad$ Retrieved from http://juke.kedokteran.unila.ac.id/index.php/majority/article/view/496

Boleng, D. T., Lumowa, S. V. T., Palenewen, E., \& Corebima, A. D. (2017). The effect of learning models on biology critical thinking skills of multiethnic students at senior high schools in Indonesia. Problems of Education in the 21st Century, 75(2), 136-143.

Bonati, F. A. (2018). Implementasi tunjangan daerah khusus terhadap kinerja guru di Kecamatan Sebuku Kabupaten Nunukan Provinsi Kalimantan Utara (Universitas Terbuka). Retrieved from http:/ / repository.ut.ac.id/7757/1/43281.pdf

Caulley, D. N. (2007). Conducting research literature reviews: From the internet to paper [Book review]. Qualitative Research Journal, 7(2), 103-104. https://doi.org/10.3316/QRJ0702103

CEA. (2018). Trends in marine resources and fisheries management in Indonesia. In $A$ 2018 Review. Retrieved from https://www.packard.org/wpcontent/uploads/2018/08/Indonesia-Marine-Full-Report-08.07.2018.pdf

Chamany, K., Allen, D., \& Tanner, K. (2008). Making biology learning relevant to students: integrating people, history, and context into college biology teaching. Cbe-Life Sciences Education, 7(Fall 2008), 267-278. https://doi.org/10.1187/cbe.08-06-0029

Chen, B. H. S., \& Huang, H. (2017). Advancing 21st century Competencies in Taiwan. Retrieved from https://asiasociety.org/files/21st-century-competenciestaiwan.pdf

Djatmiko, E. B., Grünwald, N., Nugroho, S., Murdjito, M., Supomo, H., Zaman, M. B., ... Subchan, S. (2016). Sustainable island development initiatives: Prakarsa pengembangan pulau berkelanjuta (4th Ed.). Retrieved from https:/ / docplayer.info/39356583-Sidi-sidi-profile-4th-edition-novembersustainable-island-development-initiatives-prakarsa-pengembangan-pulauberkelanjutan.html

Fauzi, A. (2019). Profile of junior high school students' critical thinking skills in answering questions related to biological concepts. Scientiae Educatia, 8(1), 51-63. https://doi.org/10.24235/sc.educatia.v8i1.4081

Fink, A. (2014). Conducting research literature reviews: From the internet to paper. Retrieved from https://libguides.usc.edu/writingguide/literaturereview

Fitria, W., Sinaga, J., Sugiono, A. M., \& Muchlas Abrori, F. (2019). Ethnobiology study of plants and animals were used in Iraw Tengkayu Ceremony in Tarakan, North Kalimantan, and its potencies as a biology resources. Biopedagogia, 1(1), 51-59. https://doi.org//10.35334/biopedagogia.v1i1.950

Francisca, A. D., \& Samsudin, S. (2018). Are biology pre-service teachers ready to implement 21st century skill in teaching and learning in Nigeria? International Journal of Academic Research in Progressive Education and Development, 7(3), 414-423. https://doi.org/10.6007/IJARPED/v7-i3/4429 
Giyarsih, S. R. (2014). Pengentasan kemiskinan yang komprehensif di bagian wilayah terluar Indonesia - kasus Kabupaten Nunukan Provinsi Kalimantan Utara. Jurnal Manusia Dan Lingkungan, 21(2), 239-246. https://doi.org/10.22146/jml.18549

Hadi, I. S., \& Kumoro, Y. (2008). Integrasi penafsiran citra dan geolistrik untuk usulan pengembangan sumber daya air pulau kecil; studi kasus Pulau Nunukan dan Sebatik. Prosiding Pemaparan Hasil Penelitian Puslit Geoteknologi 2008, 978-979. Bandung: Puslit Geoteknologi.

Haviz, M., Karomah, H., Delfita, R., Umar, M. I. A., \& Maris, I. M. (2018). Revisiting generic science skills as 21st century skills on biology learning. Jurnal Pendidikan IPA Indonesia, 7(3), 355-363. https://doi.org/10.15294/jpii.v7i3.12438

Helmiati, H. (2016). Buku data dan informasi pembangunan daerah tertinggal Kabupaten Nunukan, Provinsi Kalimantan Utara. Jakarta-Indonesia: Pusat Data dan Informasi, BALITBANGDIKLATINFO-KEMENDES PDT.

Hendarsyah, S. (2017). Strategi pengelolaan sumberdaya hayati pesisir untuk mendukung perikanan berkelanjutan di Kabupaten Bulungan Kalimantan Utara (Universitas Terbuka). Retrieved from http:// repository.ut.ac.id/7666/1/43100.pdf

Hernawati, D., Amin, M., Al Muhdhar, M. H. I., \& Indriwati, S. E. (2019). Science literacy skills through the experience of project activities with assisted local potential based learning materials. Jurnal Pendidikan Biologi Indonesia, 5(1), 159168. https://doi.org/10.22219/jpbi.v5i1.7372

Hidayanto, M., Sabiham, S., Yahya, S., \& Amien, L. I. (2008). Arahan pengelolaan lahan berkelanjutan di kawasan perbatasan kalimantan timur-malaysia. Jurnal Sumberdaya Lahan, 2(2), 105-114. Retrieved from https://media.neliti.com/media/publications/133756-ID-none.pdf

Hilmy, A. Z. M. (2018). Etnobotani tumbuhan obat untuk mengobati penyakit infeksi oleh suku dayak kenyah di Kecamatan Bahau Hulu Kabupaten Malinau Provinsi Kalimantan Utara (UIN Maliki Malang). Retrieved from http://etheses.uinmalang.ac.id/12311/1/13620021.pdf

Hiong, L. C., \& Osman, K. (2013). A conceptual framework for the integration of 21st century skills in biology education. Research Journal of Applied Sciences, Engineering and Technology, 6(16), 2976-2983. https://doi.org/10.19026/rjaset.6.3681

Husamah, H., Hudha, A. M., \& Putri, Z. A. (2019). HOTS-authentic assessment model implementation of tissue structure materials in high school of Malang: A prevalidation final draft. Prisma Sains: Jurnal Pengkajian Ilmu Dan Pembelajaran Matematika Dan IPA IKIP Mataram, 7(2), 113-125. https://doi.org/10.33394/jps.v7i2.1997

Husin, S. R. Bin. (2018). Identifikasi alat penangkapan ikan di Pulau Sebatik, Kabupaten Nunukan, Kalimantan Utara (Universitas Hasanuddin). Retrieved from http://digilib.unhas.ac.id/uploaded_files/temporary/DigitalCollection/ZDFk OTk1NTg5NTE1ODFINWYyYzE2NTVmODI2Y2FhYTM2YWYzMTRIYg==.pdf

Ilma, S., \& Wijarini, F. (2017). Developing of environmental education textbook based on local potencies. JPBI (Jurnal Pendidikan Biologi Indonesia), 3(3), 194-201.

Irham, M. (2015). Komunitas burung bawah tajuk di hutan perbatasan, Kabupaten Nunukan, Kalimantan Utara. Zoo Indonesia, 24(1), 1-14. Retrieved from https:/ / ejournal.biologi.lipi.go.id/index.php/zoo_indonesia/article/view/737

Janetos, A. C. (2020). A new biology for the 21st century. The Ecological Society of America, $7(9), \quad 21 . \quad$ Retrieved from https:/ / esajournals.onlinelibrary.wiley.com/doi/pdf/10.1890/1540-92957.9.455 
Khalil, M., Lazarowitz, R., \& Hertz-Lazarowitz, R. (2014). Biology high school science curricula for the 21st century. Creative Education, 05(16), 1464-1478. https://doi.org/10.4236/ce.2014.516164

Kurniadi, B., Hariyadi, S., \& Adiwilaga, E. M. (2015). Kualitas perairan sungai buaya di Pulau Bunyu Kalimantan Utara pada kondisi pasang surut. Jurnal Ilmu Pertanian Indonesia, 20(1), 53-58. Retrieved from https://journal.ipb.ac.id/index.php/JIPI/article/view/9289

Kustiani, H., Zaini, M., \& Mulyadi, M. (2020). Critical thinking skills of high school students in biology learning on the concept of structure and function of plant tissues. BIO-INOVED: Jurnal Biologi-Inovasi Pendidikan, 2(1), 20-25. https://doi.org/10.20527/bino.v2i1.7888

Kusuma, T., Christy, L., Dwijah, P., Tulak, I., Rantetasak, B., Elvira, E., ... Sidiq, M. (2018). Rencana aksi daerah penurunan emisi gas rumah kaca (Rad-GRK). Tarakan: Pemprov Kalimanta Utara.

Laga A, Affandi R, Muchsin I, K. M. (2015). Distribusi spasial dan temporal ikan pepija Harpadon nehereus (Hamilton, 1822) di Perairan Pulau Tarakan, Kalimantan Utara. Jurnal Zoo Indonesia, 24(1), 41-50. Retrieved from https://ejournal.biologi.lipi.go.id/index.php/zoo_indonesia/article/view/476

Maranan, V. M. (2017). Basic process skills and attitude toward science: Inputs to an enhanced students' cognitive performance (Laguna State Polytechnic University). Retrieved from https://files.eric.ed.gov/fulltext/ED579181.pdf

Maunat, Y., Ardhana, I. K., Zaenuddin, D., \& Presila, M. (2010). Etnisitas, pengembangan sumberdaya Lokal dan potensi perdagangan internasional. Retrieved from http://psdr.lipi.go.id/publications/books/item/impact-and-marketeconomy-in-rrc-copy-copy.html

Mendala, \& Suryadarma, I. G. P. (2019). Local potential of west Kalimantan's mangrove ecosystem as a study material in biology education at mangrove area school. Journal of Physics: Conference Series, 1363(1), 1-6. https:/ / doi.org/10.1088/1742-6596/1363/1/012090

Muhlisin, A. (2017). Inovasi model pembelajaran RMS untuk meningkatkan kecakapan abad 21. Prosiding Seminar Nasional Hayati V 2017, 27-36. Retrieved from

http://conference.unpkediri.ac.id/index.php/hayati/hayati5/paper/downloa $\mathrm{d} / 12 / 5$

Mumpuni, K. E., Susilo, H., \& Rohman, F. (2013). Potensi tumbuhan lokal sebagai sumber belajar biologi. Seminar Nasional XI Pendidikan Biologi FKIP UNS, 825-829. Retrieved from https://jurnal.uns.ac.id/prosbi/article/view/7922/7086

Muntiani, A. (2015). Analisis miskonsepsi biologi materi struktur dan fungsi jaringan pada hewan menggunakan certainty of response index (CRI) pada siswa kelas XI IPA. Retrieved from http:/ / digilib.uin-suka.ac.id/id/eprint/18636

Mustikasari, E., Ramdhan, M., Amry, S. N., Heriati, A., Kadarwati, U. R., Prihantono, J., \& Pryambodo, D. G. (2019). Characteristics analysis of small islands ccological dimensions in Nunukan Regency, North Kalimantan. Jurnal Kelautan Nasional, 14(1), 47-57. Retrieved from http://ejournalbalitbang.kkp.go.id/index.php/jkn/article/download/7458/pdf

National Academy of Sciences. (2009). A new biology for the 21st century. https://doi.org/10.17226/12764

Natsir, M. (2016). Pengembangan modul berbasis inquiri pada materi jaringan hewan kelas XI madrasah aliyah (MA) Syekh Yusuf Kec. Sombaopu Kab. Gowa. Makassar. 
NEA. (2012). Preparing 21st century students for a global society: An educator's guide to the "Four Cs." Retrieved from http://www.nea.org/assets/docs/A-Guide-to-FourCs.pdf

Nofiana, M., \& Julianto, T. (2018). Upaya peningkatan literasi sains siswa melalui pembelajaran berbasis keunggulan lokal. Biosfer: Jurnal Tadris Biologi, 9(1), 24-35. https://doi.org/10.24042/biosf.v9i1.2876

Novick, L. R., \& Catley, K. M. (2016). Fostering 21st-century evolutionary reasoning: Teaching tree thinking to introductory biology students. CBE Life Sciences Education, 15(4), 1-12. https:// doi.org/10.1187/cbe.15-06-0127

Partnership for Governance Reform. (2011). Kebijakan pengelolaan kawasan perbatasan $\begin{array}{llll}\text { Indonesia (No. } & 2 \text { ). } & \text { Retrieved }\end{array}$ https:/ / media.neliti.com/media/publications/45239-ID-kebijakanpengelolaan-kawasan-perbatasan.pdf

Prabowo, D. L., Nurmiyati, \& Maridi. (2016). Pengembangan modul berbasis potensi lokal pada materi ekosistem sebagai bahan ajar di SMAN 1 Tanjungsari, Gunungkidul. Proceeding Biology Education Conference, 13(1), 192-195. Retrieved from https:/ / media.neliti.com/media/publications/174711-ID-pengembanganmodul-berbasis-potensi-loka.pdf

Presilla, M. (2011). Optimalisasi sumber daya alam menuju pebangunan ekonomi dan kesejahteraan masyarakat di wilayah perbatasan. Jurnal Pendidikan Pancasila Dan Kewarganegaraan, 24(2), 102-110. Retrieved from http://journal.um.ac.id/index.php/jppk/article/view/5492

Radiarta, I. N., Erlania, E., Haryadi, J., \& Rosdiana, A. (2016). Analisis pengembangan budidaya rumput laut di Pulau Sebatik, Kabupaten Nunukan, Kalimantan Utara. Jurnal Kebijakan Perikanan Indonesia, 8(1), 29-40.

Rahmaniati, E. (2016). Peranan number heads together dalam pembelajaran biologi di kelas XI IPA. Jurnal Pendidikan Matematika Dan IPA, 6(2), 26. https://doi.org/10.26418/jpmipa.v6i2.17337

Rahmida, M. (2011). Meningkatkan hasil belajar siswa pada materi sistem gerak manusia melalui model pembelajaran kooperatif tipe teams-games-tournaments (TGT). QUANTUM: Jurnal Inovasi Pendidikan Sains, 2(2), 101-112.

Ramdiah, S., Abidinsyah, A., Royani, M., Husamah, H., \& Fauzi, A. (2020). South Kalimantan local wisdom-based biology learning model. European Journal of Educational Research, 9(2), 639-653. https:/ / doi.org/10.12973/eu-jer.9.2.639

Robinson, G. E., Banks, J. A., Padilla, D. K., Burggren, W. W., Cohen, C. S., Delwiche, C. F., ... Tomanek, L. (2010). Empowering 21st century biology. BioScience, 60(11), 923-930. https://doi.org/10.1525/bio.2010.60.11.8

Rosliana, L., Wismono, F. H., Rustan, A., Ramdani, L. E., Lutfie, W., Hidayah, K., ... Sari, M. A. P. (2015). Kajian manajemen perbatasan di Kalimantan fokus inovasi pendidikan di perbatasan (M. Darto \& W. Marian, Eds.). Retrieved from https://www.researchgate.net/publication/323026766\%0AKajian

Sadili, A. (2013). Jenis anggrek (Orchidaceae) di Tau Lumbis, Nunukan, Propinsi Kalimantan Timur: Sebagai indikator terhadap kondisi kawasan hutan. Jurnal Biologi Indonesia, 9(1), 63-71. https:/ / doi.org/10.14203/jbi.v9i1.147

Sancayaningsih, R. P., Susandarini, R., Wijayanti, N., \& Hadisusanto, S. (Eds.). (2012).

Flora dan fauna Kalimantan: Dokumentasi hasil tim peneliti ekspedisi Khatulistiwa.

Retrieved from

http://library.ukdw.ac.id/main/opac/index.php?p=show_detail\&id=42478

Sawitri, R., Bismark, M., \& Karlina, E. (2013). Ecosystem mangrove as ecotourism in 
conservation area for mangrove and proboscis monkey at Tarakan City. Jurnal Penelitian Hutan Dan Konservasi Alam, 10(2), 297-314.

SIMTARU. (2016). [Kabupaten Nunukan] - Sistem informasi tata ruang Kalimantan Utara. Retrieved June 22, 2020, from Sistem Informasi Tata Ruang website: http:/ / simtaru.kaltaraprov.go.id/web/profil/kab-nunukan

Siregar, C. (2008). Analisis potensi daerah pulau-pulau terpencil dalam rangka meningkatkan ketahanan, keamanan nasional, dan keutuhan Wilayah NKRI di Nunukan Kalimantan Timur. Jurnal Sosioteknologi, 7(13), 345-368-368. Retrieved from https:/ / media.neliti.com/media/publications/41647-none-1a41a862.pdf

Solihin, I. (2012). Strategi pengembangan perikanan tangkap di wilayah Kabupaten Nunukan Kalimantan Timur, Perbatasan Indonesia-Malaysia (Institut Pertanian Bogor). Retrieved from https://repository.ipb.ac.id/jspui/bitstream/123456789/55098/1/2012iso.pdf

Solihin, I., Wisudo, S., Haluan, J., \& Martianto, D. (2011). Pengembangan produksi perikanan tangkap di wilayah perbatasan (Kasus Kabupaten Nunukan Kalimantan Timur). Buletin PSP, 19(2), 9-18. Retrieved from https://journal.ipb.ac.id/index.php/bulpsp/article/view/4180

Sudarwan, A., \& Lay, C. (2011). Ketidakmerataan pelayanan publik dalam sektor pendidikan dasar dan kesehatan di Kabupaten Nunukan (Ilmu Politik minat Politik Lokal \& Otonomi Daerah UGM). Retrieved from http:/ / etd.repository.ugm.ac.id/home/detail_pencarian/50114

Suganda, H., \& Purwianiangsih, W. (2020). Biology teacher's perception in accommodating 21 st century learning demands. The 2 nd International Conference on Elementary Education, 2, 103-111. Retrieved from http://proceedings.upi.edu/index.php/icee/article/view/611/528

Sugiarto, Kesumawati Hadi, U., Soviana, S., \& Hakim, L. (2016). Karakteristik habitat larva Anopheles spp. di Desa Sungai Nyamuk, daerah endemik malaria di Kabupaten Nunukan, Kalimantan Utara. Balaba, 12(1), 47-54. Retrieved from http:/ / ejournal2.litbang.kemkes.go.id/index.php/blb/article/view/724

Sulistyawati, W. (2018). Tata kelola hutan mangrove di Kapubaten Nunukan (Universitas Terbuka). Retrieved from http:/ / repository.ut.ac.id/7692/1/43438.pdf

Suratsih. (2010). Pengembangan modul pembelajaran biologi berbasis potensi lokal dalam kerangka implementasi KTSP SMA di Yogyakarta. In Penelitian Unggulan UNY (Multitahun) (Vol. 10). Retrieved from http:/ / staffnew.uny.ac.id/upload/132302517/penelitian/laporan+penelitian+p otensi+lokal.pdf

Susilo, M. J. (2018). Analysis of environmental potential as a useful source of biological learning. Procending Biology Education Conference, 15(1), 541-546. Retrieved from https://jurnal.uns.ac.id/prosbi/article/view/32606

Suwono, H., Mahmudah, A., \& Maulidiah, L. (2017). Scientific literacy of a third year biology student teachers: Exploration study. KnE Social Sciences, 1(3), 269. https://doi.org/10.18502/kss.v1i3.747

Swandi, A., Amin, B. D., \& Muin, F. (2018). 21 th century physics learning in senior high school through interactive computer simulation to enhance students achievement. International Conference on Mathematics and Science Education, 3(1), 130-135.

Retrieved

from http:/ / science.conference.upi.edu/proceeding/index.php/ICMScE/article/vie $\mathrm{w} / 57$

Torkar, G., \& Kubiatko, M. (2017). Editorial. Center for Educational Policy Studies Journal, 
$7(1), 5-8$.

Triani, L., Wahyuni, S., Purwanti, E., Hudha, A. M., Fatmawati, D., \& Husamah, H. (2018). Pembelajaran I-CARE berbantuan praktikum: Peningkatan problemsolving skills dan hasil belajar siswa pada materi jaringan hewan. Jurnal Inovasi Pendidikan IPA, 4(2), 158-168. https:/ / doi.org/10.21831/jipi.v4i2.21826

Utami-Atmoko, S. S., Saputra, F., Suwarso, Husein, H. Z., Triandika, K., \& Fahrizal, D. (2017). Keanekaragaman hayati blok Sembakaung Kabupaten Nunukan Provinsi Kalimantan Utara. Retrieved from http:/ / repository.unas.ac.id/192/

Wahyudi, A. (2016). Pembelajaran berbasis karakter untuk meningkatkan daya saing dalam era global bagi siswa di daerah terdepan, terluar, dan tertinggal (Studi kasus di Kalimantan Utara, Sulawesi Utara, NTT, dan Papua). Teori Dan Praksis Pembelajaran IPS, 1(1), 1-12. https:/ / doi.org/10.17977/um022v1i12016p001

Wahyullah, D. (2014). Peningkatan kesiapan melanjutkan studi ke perguruan tinggi melalui bimbingan kelompok pada siswa kelas XI IPA 1 SMAN 1 Ngaglik (Fakultas Ilmu Pendidikan, Universitas Negeri Yogyakarta). Retrieved from https://core.ac.uk/download/pdf/33511592.pdf

Wahyunto, Ritung, S., Suparto, \& Subagjo. (2004). Peatland distribution and carbon content in Sumatra and Kalimantan. Retrieved from https://indonesia.wetlands.org/publications/peatland-distribution-insumatra-and-kalimantan-explanation-of-its-data-sets-including-source-ofinformation-accuracy-data-constraints-and-gap/

White, M. D., \& Marsh, E. E. (2006). Content analysis: A flexible methodology. Library Trends, 55(1), 22-45. https://doi.org/10.1353/lib.2006.0053

Yanti, N., Maridi, M., \& Sutarno, S. (2019). Analysis of biologi teaching material in senior high school learning biology process in Surakarta. ICEL 2019, 1-7. https://doi.org/10.4108/eai.23-3-2019.2284942

Zukmadini, A. Y., Jumiarni, D., \& Kasrina, K. (2018). Developing antimicrobial medicinal plants pocketbook based on local wisdom of Muko-Muko and Serawai ethnics. JPBI (Jurnal Pendidikan Biologi Indonesia), 4(2), 95-104. https://doi.org/10.22219/jpbi.v4i2.5436 